\title{
THE DEVELOPMENT AND EVOLUTION OF DATABASE MARKETING: A CONCEPTUAL APPROACH
}

\author{
İpek ALTINBASAK \\ Bahçeşehir University, Faculty of Economics and Administrative Sciences, Assistant Professor Dr.
}

\section{THE DEVELOPMENT AND EVOLUTION OF DATABASE MARKETING: A CONCEPTUAL APPROACH}

\begin{abstract}
The competition for reaching and satisfying customers is becoming fiercer everyday. Companies are now aware that to be successful they have to obtain information about their customers in order to build strong and long lasting relationships with them. Therefore, the understanding of database marketing, which is the gathering, saving and using the valuable customer data to the mutual benefit of the company and the customers, is becoming crucial. The article aims at defining the database marketing concept and reviewing its historical development. While discussing the phases and the driving forces leading to the development of database marketing, examples from the United States of America where database marketing is widely used are provided. Furthermore, the applications of database marketing in Turkey are investigated with a sector focus. The benefits of database marketing for involved parties are discussed in detail. Lastly, the ethical aspects related to database marketing are touched upon briefly.
\end{abstract}

Keywords: Direct Marketing, Relationship Marketing, Customer Loyalty, Market Segmentation, Database Marketing

\section{INTRODUCTION}

The increasing affluence of today's consumer society has created a market place that is rapidly fragmenting in such a way as to render the older mass marketing techniques increasingly expensive and ineffective. The effort in consumer marketing to distinguish one's real prospects from the undifferentiated mass is increasingly important. In the past, companies have not used the information provided to them by the customers effectively. It is the advances in information technology, which enabled and speeded up the collection, retention and use of customer information in the creation of a competitive advantage for the companies.

Today, the use of customer information as a source of marketing information, as a means for customer communication and as a driver of marketing strategy, has become prevalent in the marketplace. With the increasing value of customer information, database marketing's

\section{VERI TABANLI PAZARLAMANIN GELISSIMÍVE EVRIMI: KAVRAMSAL BIR YAKLAŞIM}

Özet: Hergeçen gün müşterilere erişmek ve tatmin etmek konusundaki rekabet daha da çetinleşmektedir. Kurumlar müşterileri ile güçlü ve uzun süreli ilişkiler kurarak başartl olmak için müşteri bilgisinin ne kadar önemli olduğunu anlamış bulunmaktadırlar. Böylece, değerli müşsteri bilgisinin toplanmast,saklanmast ve hem müşteri hem firmaya fayda yaratacak şekilde kullantlmast olarak ifade edilen veritabanlt pazarlamanun anlaşılmast ve etkin kullantmast daha da önemli bir hale gelmiştir. Bu makale, veritabanl pazarlama kavramını ve tarihsel gelișimini incelemeyi amaçlamaktadır. Veritabanlt pazarlamanin evrelerini ve gelişiminde rol oynayan itici güçleri ortaya koymanın yanısıra, çalışmada, veritabanlı pazarlamanın yoğun olarak kullanıldı̆̆ı Amerika Birleşik Devletleri'nden örnekler verilmekte, Türkiye'deki veritabanlı pazarlama uygulamalart farklı sektörler bazinda irdelenmektedir. Ayrica, etkin veritabanlt pazarlama uygulamalartunn şirketler ve müşteriler açısindan faydalart detayl olarak ele alnmakta ve son olarak veritabanlt pazarlamantn etik boyutu değerlendirilmektedir.

\begin{tabular}{ll} 
Anahtar Kelimeler: & $\begin{array}{l}\text { Doğrudan Pazarlama, Ilişkisel } \\
\text { Pazarlama, Müsteri Sadakati, Pazar } \\
\text { Bölümlemesi, Veritabanlt Pazarlama }\end{array}$ \\
\hline
\end{tabular}

popularity also increased at a rapid pace in the United States and European countries.

The objective of this paper is to review the issues related with database marketing and touch upon its applications in Turkey. After an overview of the definition of database marketing and its development, the sectors which use it more effectively in the United States are presented. The applications of database marketing in Turkey are investigated with a sector focus. Afterwards, the benefits of database marketing for involved parties are discussed. As last, the social and legal considerations related to database marketing are touched upon briefly.

\section{DATABASE MARKETING}

\section{II.1. Definition of Database Marketing}

To describe the same phenomenon, which is "the recognition of treating each customer individually regardless of the number of the customers to be 
addressed" several terms are used interchangeably [1] According to certain authors there is little distinction between database marketing and direct marketing and they can be considered as synonymous [2,3]. Brown [4] also listed the terms database marketing, individualized marketing, one-to-one marketing, bonding, etc. as meaning the same concept.

Several attempts have been made to define database marketing. Different authors emphasized different aspects of database marketing in giving a definition. Database marketing is described as "gathering, saving and using the maximum amount of useful data about your customers and prospects, to their benefit and your profit" [5]. As there is no generally accepted definition of database marketing, Roberts and Berger [6] stress the segmentation capability as the main strength of database marketing in their definition. They state that "database marketing is a segmentation process carried out in a computerized database of customers and prospects using statistical analysis and models in order to target individuals instead of the entire segments of customers and prospects". Similar to the approach of Roberts and Berger [6], Forcht and Cochran [7] also define database marketing as the broad term to describe the type of market segmentation used by businesses through knowledge discovery.

However, by borrowing ideas from different authors, DeTienne and Thompson [8] define database marketing from a strategic perspective. According to the authors, database marketing is "the process of systematically collecting, in electronic or optical form, data about the past, current and/or potential customers, maintaining the integrity of the data by continually monitoring customer purchases and/or by inquiring about changes status and using the data to formulate marketing strategy and foster personalized relationships with customers". Fletcher et al. [9] also state that database marketing uses the data to identify and communicate with precisely targeted customers and prospects, within a planned framework, while creating long-term customer relationships. The authors point out that the immediate aim may be tactical, but the ultimate aim is to maximize lifetime customer value.

Marketing databases have become an integral asset to businesses, largely due to the evolution of relationship marketing and the realization that in order to be competitive, companies need to build a relationship with their customers which is based on more than just price. Database marketing aims at building a profitable individual relationship with each customer [8]. In the past, relationship marketing was conceived as an approach to industrial and service markets. With the developments in database marketing within an increasingly competitive and fragmented marketplace, relationship marketing has been extended to applications in consumer markets [10].
Companies are now aware that to build loyalty, strong and durable relationships must be created [11]. Since relationship marketing stresses personalized customer interaction, it is found to be very relevant in the formation of database marketing strategies [12].

\section{II.2. The Phases of Database Marketing}

The first phase of database marketing is to gather raw data about customers. There are various external sources such as governmental records and data collection companies from where the information can be obtained. However, the company can also collect information about its customers through recording every contact they make with the company. However, not to be overloaded with data, the marketing manager must identify the internal sources of data and develop systems to capture the data for input in the database. If additional data is required, further research to collect it from external sources must be carried out [6].

The second phase involves data mining. Once an organization begins to systematically collect data, it quickly finds itself confronted with huge amounts of it. The primary challenge is how to make the database a competitive business advantage by sifting through the enormous stores of seemingly meaningless facts and converting data into useful information. Forcht and Cochran [7] state that data mining is an interactive process that involves assembling the data into a format conducive to analysis. The data must be cleaned from errors and flaws. The aim of data mining is defined as discovering links between customer behavior and any variable that might potentially be useful [13]. Once the data are mined to establish patterns and make predictions, the results must be tested and verified. This means that several methods need to be tried and the results compared [14]. Although the entire process is extremely time consuming and costly, data mining is crucial for the effective use of information.

The following phase consists of using the data in building relationships with the customers. It is proposed that to make this relationship beneficial and attractive for the customer a value must be offered. Ravald and Gronroos [15] suggest that a customer-oriented value added to the offer is an important constituent of the relationship between the company and its customers. Unless there is a value proposition, database marketing is perceived as a threat to privacy (this issue is investigated in the last section of the paper in more detail). However, it is also argued that the issue has to shift from privacy concerns to a commercial negotiation in which consumers demand a reward such as personalized benefits, for having provided data about themselves [16].

Database marketing has tremendous potential for making many aspects of the marketing process more cost 
effective and influential. However, to achieve this, a great deal of effort is required. Perhaps even more important, it requires a new way of thinking on the part of the marketing personnel in most organizations. It is therefore imperative that, before database marketing is adopted, marketers ask themselves how the database will be useful. They can then measure prospective costs against potential benefits. Furthermore, they can plan the necessary actions in a way as to provide maximum effectiveness.

\section{II.3. Alternative Media for Database Marketing}

After mining the data, marketing managers can use the information for different purposes such as product development, cross-selling, new product launching, and establishing close relationships with the customers etc. However, the medium used in reaching the customers play an important role in the acceptance or rejection of database marketing.

As Blattberg and Deighton [17] point out addressable marketing is not new: mail and telephone have been important marketing tools for many years and the sales force even longer. Face-to-face, personal selling is the oldest form of direct marketing. Today, several businesses use this method to contact their customers. Another widely used medium for direct marketing is mailings. Mail-order marketing through catalogs has been around beginning from the early 1900 s [8]. As a result of the advances in technology, today the customer data is kept and used more effectively. Therefore, the abovementioned methods are used in a more targeted and sophisticated manner than they were used years ago. Telemarketing is another form of direct marketing. As there may be human interaction in some forms of telemarketing, there is a particular need to understand how rapport might be developed on the telephone [18].

Besides the traditional media, technology offers new media for direct marketers. These are interactive television, electronic kiosks, on-line services and Internet/World Wide Web. The strength of the new media marketplace is in its ability to give instant access to incredible amounts of information in a cost effective manner also enhancing customer relationship management [19]. This information is stored and distributed in digital form. Furthermore it is available on demand, when a consumer needs it, not necessarily when a marketer wants them to receive it. Once created, it requires little human intervention on the part of the marketer, except for periodic updates. Furthermore because they are interactive, they offer the opportunity to customize messages to each customer [3]. For example, the mail order catalog marketing can be turned to an interactive relationship with the use of computers. Each catalog's content may evolve in response to demand because the marketer can use the computer to assemble a different catalog for every customer [17]. The introduction of new electronic media enabling interactivity seems to create major changes on how marketing is handled.

\section{HISTORY AND DEVELOPMENT OF DATABASE MARKETING}

In this section the origins of direct marketing and the driving forces of its development will be investigated.

\section{III.1. History and Origins of Database Marketing}

Years ago, direct marketing where salesmen met with customers personally was the primary way of marketing. However, because of cost concerns, but especially with the advent of mass media, this type of marketing became eventually less applied. Actually, database marketing's origins can be traced directly to the field of direct marketing, which in turn emerged from the field known as "mail order" prior to the late 1960s in the USA. Sears Roebuck, Montgomery Ward and other catalog companies pioneered strategic mail-order marketing, beginning in the early $1900 \mathrm{~s}$ to analyze subscriber lists and channel resources toward promising customers. Although certain mathematical models for analyzing customer data were developed, even at this early date, the manual application of these models, however, proved difficult. To simplify the analysis and strategy implementation, companies lumped customers into broad categories. Thus, an early response to the availability of customer data was market segmentation [8].

During the 1950s, increased emphasis on customer access led to the proliferation of lists of potential customers. The compilation and marketing of the lists themselves became a substantial industry. However, it was not until 1960 that mass customer data was captured electronically [8]. Although the scope of database was defined much narrower than it is today, the term "database" was first coined at an American military seminar in 1963 on "development and management of computer-centered database" [20].

In the late 1970s a small group of American direct marketers at American Express was looking for a way to improve the response rate to direct mail credit card solutions. The candidates for card membership, which constitute $5 \%$ of the population, were identified by using advanced demographic and geographic segmentation techniques. However, traditional segmentation was not adequate to identify, out of this demographic pool, prospects that had a sufficiently high probability of mailings satisfactory. The direct marketers believed that through analyzing the billing records of the company, the purchase behavior of the current card members could be investigated. Given assistants and a small budget, the teams worked hard and developed techniques to generate 
savings in mailing costs while maintaining or increasing the number of new customers acquired. Management permitted them to reinvest cost savings in improved technology. Thus was born the discipline of database marketing [6].

According to Blattberg and Deighton [17], the cost of holding a consumer's name, address and purchase history on line has fallen by a factor of a thousand since 1970 s and is still continuing to fall at a rapid rate. According to these authors, direct marketing is not new but low-cost electronic management is new. Due to increased computer efficiency, several sophisticated analysis and statistical tools were developed in 1980s. The developments continued with a faster pace in 1990 s and today marketing databases have spread to industries other than direct mail.

\section{III.2. Driving Forces of the Development of Database Marketing}

Although the advances in technology is the main driver speeding up the fast development of database marketing, other factors such as change in market behavior; and the decreasing effectiveness of mass media, in turn affected the rise of database marketing in the last 20 years. Those factors will be investigated below.

\section{III.2.1.Advances in Technology and the Increasing Value of Information}

Today, the marketing environment is more dynamic and volatile than ever. As a result, competition is becoming fiercer. In such an environment knowledge or information emerges as an asset, often with significant market value [21].It is also argued that the basic economic resource is no longer capital, or natural resources, or labor, but is and will be knowledge or information. Among the types of knowledge considered to be very important are (1) knowledge about consumers (2) knowledge about best practices/ effective processes (3) knowledge about the company's competencies and capabilities, and (4) knowledge about a company's own products and services [22]. According to the author, as we enter the new millennium, the evolution and degree of utilization of knowledge management systems within individual corporations will play an important role in their success or failure. Consequently, to handle the increasing external and internal information flow and to improve its quality, companies will need to take advantage of the opportunities offered by modern information technology (IT). IT has a key role in enabling the companies to gather, maintain and process the information, whereby creating a competitive advantage [23].

According to Peattie and Peters [24], the middle of the $1990 \mathrm{~s}$ is being acknowledged as a turning-point within the field of information technology. During its development, from 1960 to the early 1980s, IT was dominated by mainframe computers and issues of data processing. It was bulky and expensive. The main area of usage was computation. Even such, it meant new opportunities for marketers such as production flexibility and product quality, together with massive new customer and order databases to analyze. These systems allowed new and better information used in marketing planning and communicating to internal customers.

The second age, that of "computers" emerged from the mid 1980s and was symbolized by personal computers (PCs). The PC encouraged decentralized computing within companies, with systems increasingly owned and developed by end-users instead of technical specialists. The customer data was better tracked and analyzed however, the internal and external communication was limited in scope. During 1980s, IT became increasingly important to the development and execution of corporate and marketing strategies. IT was increasingly applied in the search for competitive advantage [25]. This caused IT to be seen not just a useful tool for marketers but also something that represented a strategic challenge for them to manage.

As the third age evolves, the most important theme that emerged is communication and connectivity. With IT moving into the realms of communication and connectivity, its centrality to marketing increases. This is because formal marketing exists to connect procedures and consumers who became distanced and estranged by the process of industrialization and the emergence of mass production for mass markets. The third age IT allows companies to link directly to customers to enable new relationships and interactions to develop [24].

Fletcher and Peters [26] believe that the age old marketing concept-that the customer is king- has been given new life and new corporate relevance by the development of low cost, user-friendlier computerized information systems. However, this customer focus requires large investments in the information management and information technology. As Evans [13] points out, in many industries not widely considered information businesses, information represents a large percentage of the cost structure. But why do the companies make such big investments in IT and why is information so valuable? As mentioned previously, it is believed that one of the essential ways of gaining competitive advantage is building and using information. Furthermore, marketing efficiency is believed to be measured by changes in the asset value of the firm's customer base over time [17] For example Glazer [27] stresses that the organizing asset around which the full range of information-intensive strategies is based on Customer Information File (CIF). It is a single virtual database that captures all relevant information about a firm's customers. The database is described as "virtual" since, while operating as though it 
were an integrated single source housed in one location, it may in reality be comprised of several isolated databases stored in separate places throughout an organization.

Fletcher et al. [9] point out that database marketing is customer knowledge as part of marketing information system, to be used for business development and strategic planning. Database marketing is a new approach to marketing, being a new way of doing business and requiring a redefinition of the relationship between a company and its customers. It is through the advances in IT that companies can build direct relationships with their customers. Zineldin [28] argues that relationship marketing is only possible with the help of advanced technology. That's why the author calls it "technologicalship marketing". Furthermore, IT tools are the most important factors to effectively and efficiently create, develop, and sustain business-to-business and business-to-customer long-term relationships which are essential for database marketing.

\section{III.2.2.Change in Market Behavior}

In the last two decades of the $20^{\text {th }}$ century, it is observed that the market behavior has changed significantly. Evans [13] states that the fragmentation of the markets started even as early as late 1970s. The household behavior is observed to be nuclear where family members began to behave more independently and acquire different choices for products instead of one common alternative. The market fragmentation can be explained by an increasing trend toward individualism. In fact there is evidence to suggest that people are becoming more oriented to self-expression and "inner-direction" as opposed to mass social movements. O'Malley and Tynan [10] also observed that individualism led to a proliferation of sub-groups or segments within society on various criteria. As a result, companies need to communicate with market segments in more individual and focused ways. At the same time, people are more ready to accept, appreciate and respond to being targeted with relevant and individualized marketing.

In time, markets have become demassified and this has been a major trend aiding to the growth of database marketing. The increase in the number of working women made time saving purchase methods more appealing. Schoenbachler et al. [5] also point out that one societal shift has been a significant decrease in the relative amount of leisure time available to consumers. As a result, the consumer is searching for a more efficient method of shopping to fulfill needs. Furthermore, it is observed that a more broadly educated and more discerning consumer with increasing discretionary spending and purchasing power emerged. The continuing trend away from cash as the means of payment to credit, debit and smart cards, through the post and over telephone and Internet cables, has enabled purchase behavior to take place when the consumer wants it- 24 hours a day and from the arm-chair, office phone or even traveling laptop computer. The customers became more demanding in terms of the characteristics of the products and services they would prefer. The increasing demand for personalized treatment and convenience from the consumers, coupled with the difficulty in segmenting such a fragmented society for the manufacturers, fastened the popularity of database marketing.

Manufacturers must also take some responsibility for increasing fragmentation of markets. As many consumer goods reached maturity in the late 1970s and early-1980s, manufacturers began to fragment the markets as a means of obtaining growth. New, more specialized products were aimed at limited segments of consumers. These niche markets have increased the wastage ratio in traditional advertising. O'Malley and Tynan [10] believe that this proliferation of products and segments has been further exacerbated by the phenomenal growth of retailers' own brands. As a consequence, more direct methods of reaching consumers such as database marketing become vital to provide effective communication.

\section{III.2.3.Declining Effectiveness of Traditional Media}

An increasing emphasis on leisure interests has led to more intense competition for consumers' time and attention [10]. Market fragmentation has resulted in diminishing audiences for individual media and media costs have soared. Audiences are fragmenting as more TV channels appear, along with more newspapers and magazines- all with advertising space to fill. The increase in the number of alternative media choices dilutes the effectiveness of mass marketing efforts. With the increase in the number of products offered, flooded with numerous mass marketing messages, from various sources, consumers are also more skeptical and less likely to attend to ads [5]. Furthermore, the cost of buying time has gone up faster than inflation in the past 15 years in U.S. This is because of the soaring value of commercial slots in the diminishing number of programmes that pull in big crowds. Even if the slot is purchased, viewership cannot be guaranteed as a result of "zapping" concerns $[16 ; 13]$. Most important of all, consumers are indicating a preference for communications, which are personalized and directed specifically to their needs, typically based on past purchase transactions. Database marketing is seen to have the potential to overcome the difficulty of this fragmentation through personalized messages. As Hutton [29] states, in an era where mass marketing is loosing its effectiveness, individualized or database marketing is returning as a valuable tool to create competitive advantage 


\section{DATABASE MARKETING IN THE UNITED STATES OF AMERICA}

Direct marketing in the USA became a boom industry in $1980 \mathrm{~s}$, with direct mail sales growing from $\$ 15$ billion to $\$ 46$ billion (twice the rate of retailing during the same period) and the number of active direct marketers growing to 13,000 . Similarly, industrial mail order grew at 20-25\% annual rates going into the late 1980 s. Furthermore, the share of direct marketing in advertising spending has increased to $40 \% \mathrm{~s}$ in USA in the late 1980 s [30].

According to Schoenbachler et al. [5] direct marketing, the industry from which database marketing evolved, is a high-growth area with current growth twice that of US gross national product. The mentioned authors support their view with several data. The 1997 results of WEFA Group study commissioned by the Direct Marketing Association suggest that the direct marketing industry contributes directly or indirectly $5 \%$ of the nation's annual gross domestic product. While US GDP is expected to grow $6.5 \%$ in the next five years, the direct marketing industry is expecting over $10 \%$ growth in the same period. According to the estimates of Direct Marketing Association, of the $\$ 248$ billion spent in America in 1996 on all kinds of marketing, 58\% was for some form of direct marketing $[7 ; 16]$.

A study (1997) of direct marketing executives found that $80 \%$ of businesses (none of those in the business-to-business category) have some form of database, with two-thirds of these indicating plans for a database upgrade during 1996. The majority of these databases are small, with less than 100,000 records. Most were developed for less than $\$ 100,000$, although large companies spent as much as $\$ 5$ million on database development and maintenance [5].

These numbers are especially integrated in the paper to portray the huge size of database marketing in the United States of America. Direct marketers are not the only ones using database marketing. Database marketing is used excessively almost in every industry in the US.

Airlines were among the first traditional mass marketers that started to use database marketing [31]. The first frequent traveler program was launched in 1981 by American Airlines in the aftermath of airline deregulation in the United States. The company was intended to create consumer loyalty by increasing switching barrier or increasing the costs of switching (i.e., loosing benefits). The program provided significant rewards for loyalty in the form of free airline tickets. In addition members were rewarded with convenience (lounges set aside for members and early boarding privileges) and comfort (free upgrades). The club members also received some form of communication from American Airlines at least monthly, usually in the form of an earnings statement, encouraging continuing loyalty and relationship maintenance [5].

Other travel businesses, such as hotels (Hilton, Hyatt, Holiday Inn., etc.), and car rental agencies (Budget, Avis, etc.), soon followed and launched their own frequent-user program or went into joint programs with airlines. Even restaurants in America (i.e. Los Angeles Restaurant) offered frequent dinner programs to their customers. Oppermann [31] states that, today, most of the loyalty schemes of airlines, hotels, car rental agencies, credit cards and other companies are heavily interlinked.

Among pioneers in consumer goods sector is Philip Morris. Banned from traditional media the company pioneered a database strategy, which aimed not only to market products, but also to lobby efforts against potential government anti-smoking campaigns. Philip Morris's database contains over 26 million smokers as of 1997 [5]. Procter\&Gamble and Colgate Palmolive also are among the firms using database marketing in the United States [32].

The finance sector is among the heavy users of database in the United States. For example banks are using database marketing to collect household financial information that enables them to target customers that may be prospects for additional services that are not currently being used by the customer. In addition, the database allows the banks to market to the most profitable segments of their communities. It is stated that many banks look for improving their profits through information-based continuous relationship marketing [33]. A better understanding of customer needs can help them to acquire new customers, sell more products to those customers, and prevent other customers from taking their business elsewhere. It is stated that in two years, one large North American bank trebled the number of products it sold per client household by using need-based profiling. Another one pursuing the same approach saw a $60 \%$ increase. Furthermore, intelligently used, database marketing reduced mailing sizes for direct mail campaigns by as much as two-thirds [33].

It is crucial that this type of marketing approach be developed carefully. Many of the fast growing and profitable US financial companies such as Capital One that have stolen business from traditional multiproduct banks are experts of it. Capital One is winning big in cutthroat world of credit cards through database marketing and never stopping innovation for information technology [34]. The key to adoption of the service is the Digital Data Solutions tool kit which lets solution providers like Capital One integrate data from the database directly into contact managers and call center applications. Through this software solution, providers could create a link between database and call tracking 
software and use information about an incoming caller to trigger a database look-up before someone actually answers the phone. The result is more informed customer relationship representatives. The mission of Capital One is "to deliver the right product, to the right consumer, at the right time". Through the use of extensive technology customer satisfaction is increased while also moving up the profitability of the company. As a result Capital One believes that this is more than a credit card strategy but a marketing revolution [34].

Other financial services companies such as Merrill Lynch are aware of the centrality of new client prospecting for their business growth. Consequently, database marketing is also favored by those institutions. For example, Labe [35] describes how databasemarketing efforts increase prospecting efforts in Merrill Lynch.

Database marketing is also frequently used in the retailing sector. As retailers have direct contact with end users, they can collect information from them through loyalty schemes. Big department stores from upscale Saks and Brooks Brothers to Wal-Mart and K-Mart have huge databases in hand and develop their marketing strategies accordingly. The information helps the retailers in many areas such as shelf design, decisions about the product portfolio to be carried, better service procurement etc.

Although there were many mail-order catalog retailers in United States for more than a century, retailers such as Newman-Marcus, Marshall Field and J.C. Penny are using database marketing as an effective part of their marketing strategy [36]. The universe of mail-order catalogers exploded from 4000 catalog marketers to 10,000 ranging from giants to the smallest [32]. Big catalog retailers such as Spiegel and L.L. Bean exploit the interactivity of database marketing through tailoring there catalogs according to the individual needs of the customers [17].

Automotive industry also has recognized that the current and past customers of the companies are the best prospects for future sales. By keeping in continual communication with their customers automobile manufacturers such as General Motors, hope to ensure repeat sales opportunities [37]. General Motors also teamed up with Master Card to offer GM Card. The database stands over 12 million card-holders, as of 1997. Blockbuster Entertainment is another example of successful database marketing implementation. Throughout the years the company prospered through database marketing activities. The company has built a database of 36 million households. The application of database marketing not only promotes additional rental revenue for the company, but also builds relationship with the customer by offering suggestions as to what to rent according to the customer's taste [38]. As described by
Woodside [39], advertising agencies also are considering the advantages of the integration of advertising in database marketing. It is believed that especially under high involvement conditions, when advertising is incorporated into database marketing, the customer will be more likely to notice and be motivated to elaborately process the contents of the ad and to request the linkage offer.

Business-to-business sector has always been a heavy database marketing user in the USA. For example companies like Fed-Ex, DHL base all their marketing action on the customer data they have. They developed a different department with analysts especially dealing with data mining and supporting the marketing department. In this analysis department, through a cluster analysis, different customer segments have been identified. Each segment leader proposes the most suitable alternatives to the customers in this segment. It is his/her job to sort out the services and messages those customers need. All of the marketing strategies are designed according to the analysis carried out on the customer data.

Telecommunication companies such as AT\&T, $\mathrm{MCI}$ and Sprint and oil companies like Exxon and Mobil have also got engaged in database marketing [32].

The booming figures related to database marketing reveal the wide spread use of database marketing in the United States. However, as observed especially the service sector including airlines, hotels, car rental companies; all financial services organizations including banks and brokers; insurance companies and of course retailers are among the heavy users of database marketing. This does not mean that manufacturers in different sectors are not interested in it. On the contrary database marketing broadened its appeal to include blue chip industrial and consumer companies such as IBM, 3M, Sony, Westinghouse, American Express, and Procter and Gamble [36].

In 1994, $56 \%$ of all manufacturers and retailers stated to build up a database, an additional $10 \%$ claimed to have planned to do so and $85 \%$ stressed that they would need database marketing to be competitive past the year 2000 [38]. As Schoenbachler et al. [5] state, every type of business, profit or non-profit, consumer or business-to-business, selling products or services has a need for some type of marketing database. Although these database needs may vary in size, level of detail and applications, they all serve the primary objective of providing information for knowledge-based decision making.

\section{DATABASE MARKETING IN TURKEY}

The use of database marketing in the United States and European countries is amazingly wide spread and is 
expected to grow at an increasing pace. When compared with those countries, database marketing is still in its infancy in Turkey. Although many companies are becoming more and more aware of the importance of the customer data, database marketing is limited to a few industries such as retailing, banking, pharmaceuticals, insurance and telecommunications in Turkey. Furthermore, whether they use the database marketing effectively or not is debatable.

As it is a newly emerging subject, there is no scientific research carried out on database marketing in Turkey. A qualitative study [40] about the use of database marketing in the Turkish retailing and banking sectors and the ethical considerations of marketing managers of the investigated companies can shed light on the understanding of this phenomena. The following statements about database marketing in Turkey are based on this study and personal observations.

It is observed that several companies have started to collect information about their customers in Turkey. However, most of the collection is done on a random basis without a strategic perspective. The sole objective is forming a database but as the database is not polished and updated periodically, its relevancy is questionable. Even the firms that have collected information about customers are not using it effectively.

There are several reasons why the data collected is not being used. One is the organizational infrastructure. Most of the companies do not have the know-how and technological capabilities to mine the data. As explained in the previous sections, database marketing requires an initial investment in technology. Consequently, the vision of the top management related to the effectiveness of database marketing plays a critical role. Besides the technology, in many Turkish companies a special staff dealing with the refining and analysis of the data does not exist. The marketing managers can only guide such an analysis. Expert analysts have to take care of the mining of the data and the further analysis. The technological and human resource investments are crucial for a company to carry out a successful database marketing activity.

The other issue limiting the use of database marketing in Turkey is related to the infrastructure of the country. The company managers state that most of the data is either dirty or obsolete. It is not easy to reach a customer to provide an update. For example, there is no single identification number for each citizen so that companies can keep track about them and update the information obtained. The only source for updating the obsolete data is again the customer himself. The companies offer several advantages to make the customers update their personal information. The mail service also is not very well developed and is expensive. Although telephone is an effective medium, it can only be used for projects that can justify the high costs occurring as a result of telemarketing. However, it can not always be possible to reach the targeted customer by phone if the data is not updated.

Despite all these problems, with increasing competition, companies see the benefits in bonding with their customers to create loyalty for their products and services. The major sectors using database marketing in Turkey are retailing, banking, telecommunications, insurance and to a certain extent pharmaceuticals. It has also be noted that especially group companies operating in different sectors favor database marketing (i.e. Boyner, Koç and Fiba). This can also be tied to the cross-selling opportunity provided by database marketing activities. Each group company operates as a separate profit center in the group. Therefore, information sharing among the various companies of the group is not considered for the time being. However, in the future it can be a valuable opportunity to learn about the different aspects of the consumers for the companies.

The main vehicles used for data collection in Turkey are credit cards and store cards. The banking sector encourages loyalty through point collection and rewards system. They are trying to find more attractive prizes for motivating the customers to participate in loyalty schemes (e.g. the joint promotion of Garanti Bankas1 with THY offering mileage points for each purchase: Shop\&Miles Card). Acknowledging the growing importance of customer information several banks such as Koçbank, are getting engaged in setting the infrastructure and have started investments. The international banks are better organized to benefit from the advantages of database marketing. Using the knowhow provided from abroad and the accumulated experience as result of different applications in different countries, they can carry out efficient database marketing activities. For example, Citibank has an advanced technological and managerial infrastructure, supported by its headquarters. The major advantages that database marketing provides are the ability to measure each database marketing activity's effectiveness, better segmentation and targeting, the exploitation of crossselling activities and most important of all according to the company managers, the new product/service development to better serve the customers.

Retailing sector is also interested in loyalty. To make the consumers loyal to their shops, they offer instant price reductions and rewards through point collection to the store card holders. Retailers hold a huge database about their customers. They can observe the shifts in their purchase behavior. Having already established the technological infrastructure, they are aware of the value of the information and do not prefer to share it with any other company. They also started to use kiosks as an interactive medium to contact, receive information from 
and provide information to the consumers. The big retailers are also considering Internet as a direct channel to reach the customers and serve them. The multimerchant retailer cards also became very popular in Turkey, as a result of the installment alternative they provide in payments. By increasing the number of the participant retailers, they look for increasing the attractiveness of their cards.

Telecommunications sector has a distinct advantage over the other implementers of database marketing. Besides having fresh data about the customers (their current telephone numbers at least) they also have full control of the medium used to reach the customers. Lately, telecommunications companies are attempting to benefit more from this advantage. However, there is still room for more effective implementation of database marketing in this sector and the opportunity for it still remains.

Insurance and pharmaceuticals companies also are perceived to be among the users of database marketing. However, the extent of the usage efficiency and the stage of development database marketing strategy are not investigated yet. The insurance companies use customer data for cross-selling and new product development. On the other hand, pharmaceutical companies collect data about the doctors and keep track of them to better promote their products.

It is observed that even the first adopters of database marketing are slow in adapting the company and marketing strategies to make full use of this method. It is also another fact that the Turkish consumers are not aware of the value of the information they provide about themselves. Consequently, the companies have a large ground for information collection. As it is a new method for Turkey, the consumers are not yet concerned about the violation of their privacy rights. However, companies learning from the experiences of their foreign counterparts, should not make the same mistakes they have done. Observing the fast development of database marketing abroad, it is expected that the same situation will take place in Turkey. However, marketers willing to start a healthy, long-term relationship with their customers have to be very careful in dealing with privacy related issues.

\section{THE POSSIBLE OUTCOMES OF EFFECTIVE DATABASE MARKETING}

In this section the possible outcomes of effective database marketing both for companies and consumers are presented.

\section{VI.1. Outcomes for Companies}

Database marketing offers several opportunities for companies pursuing it as an integral part of their marketing strategy. As the examples of firms using database marketing show each firm's concern or expected outcome may not be the same. However, through an effective use of database marketing companies may benefit from it in several ways. These outcomes are presented below.

\section{* Better Segmentation and Positioning}

Individual uses of or benefits sought from a product class/form/brand/options have been found to differ in terms of consumer's individual preferences, choice behaviors in the market place, as well as their effective responses to marketing actions of firms [41]. Therefore, firms offer a multitude of products and brands to different market segment [42]. However, it is not easy to define the different segments in such a fragmented market place. It is database marketing that enables the marketing managers to contact directly with the consumers, learn about them and carry out more targeted marketing activities. Database marketing is an attempt at target marketing strategy. Furthermore, through the acquisition of detailed and individualized information, an increased opportunity for niche marketers arises. Companies are able to identify segments of the market that can support a specialty targeting approach [5]. The objective is always creating more effective and efficient ways of reaching individual customers in order to satisfy their unique needs. Database marketing makes individualized marketing a reality $[43 ; 7]$ Furthermore, database marketing allows marketers to segment their markets more efficiently and to offer many choices to customers without the high cost of retail marketing $[5 ; 44]$.

\section{* Differentiation and Customized Offers}

Database marketing allows the managers to observe and appreciate the differences among consumers. As they are different, once you identify your customers, differentiating them will help the company to focus its efforts so as to gain the most from the most valuable customers [45]. Through learning more about the current customers and potential ones, the marketing managers can also differentiate their products accordingly [7]. Differentiation is in any way, part of individualized marketing. Not only the products but also every element of the marketing mix can be differentiated as a consequence of the customer knowledge [46]. The promotions are better targeted and the communication strategy will be designed according to the individual needs of the customers. Furthermore, in contrast to mass media campaigns, direct campaigns allow marketers to communicate with customers without the knowledge of competitors [5]. The information gathered about the needs 
and expectations of the customers can also be used for new product development and quality improvement of existing products/services [2].

Another benefit of database marketing is the opportunity for cross-selling. By maintaining a record of customer purchase history in a database, marketers can identify opportunities to sell additional products that customers may be interested in. The diversity of the product portfolio of the company will also be helpful in pursuing such an approach.

One of the major strengths of database marketing is its measurable effectiveness. The effectiveness of television advertising and other forms of mass media promotion are very difficult to measure. However, it is very easy to measure the return on direct marketing outlays. Data can be readily collected regarding how much it costs to contact a customer and to measure the monetary value of placed orders [43;7]. Database marketing efforts are measurable: promotions can be tested to determine what types of offers are most effective, the best timing of offers and the segments that are most responsive to offers [47].

\section{* Customer Acquisition}

The eventual aim of companies is to increase their sales and profits. One way of achieving this is increasing the number of customers served. Knudsen [43] states that database marketers operate with suspects-all customers belonging to the basic market potential of the company, prospects- more valuable potential customers, and actual customers. Through the use of database modeling and other prospect screening techniques, companies can more effectively target prospects that are most likely to buy. As a result of the effective use of databases, the marketing department is expected to turn the prospects into regular customers of the company. The tailored messages, products/services according to the needs of the prospects are expected to pursue this goal. Only the customers who are expected to buy receive the promotional message. As a result the company saves money and the customer is not irritated by endless streams of junk mail [5]. Glazer [27] argues that "event-oriented prospecting" is a very effective tool to capture the customer. By anticipating the needs of potential (also those of existing ones) customers, the firm can create the appearance of literally "reading the customer's mind".

\section{* Customer Retention and Relationship Building}

Today, marketers know that it is easier and less expensive to get an existing customer to buy again than it is to acquire a new customer. Consequently, the retention of the customer is crucial for the success of companies. Through building intimate relationships with the customers, making them feel that they are important for and valued by the company, the marketing managers aim at keeping the customers loyal to the firm. Furthermore, the conversion of one time customer to a loyal one is the objective of database marketing [5]. The examples of airlines, hotels etc. demonstrate that database marketing, particularly loyalty programs, encourage customer retention and reduce customer erosion. Database marketing is an offshoot of the marketer's desire to develop an enduring, mutually beneficial relationship with individual consumers [8]. A long-term perspective and concentration on customers' values and needs are found to be crucial for the successful implementation of relationship building activities [28]. Through regular contacts repeat sales and cross selling opportunities also are enhanced [48].

In building and maintaining relationship proactivity plays an important role. As a result of the relationship established and knowledge acquired, the company is expected to act in a proactive manner to the demands of the customers. Informative communications focusing on related products and services can be sent out to customers who have inquired or made a related purchase in the past $[5 ; 7]$.

\section{* Easy Market Entry}

Iyer and Hill [36] present that database marketing also offer opportunities for new market expansion. If information about the potential customers can be collected this will lead to a fast implementation of marketing strategy. Furthermore, market feedback is quick and it is a relatively easy and cheap form of market entry. Availability of mailing lists, language commonalties, extensive use of credit cards and adequate communication facilities are considered among the factors affecting the success of international direct marketing efforts.

As pointed out above, when implemented effectively, database marketing provides several benefits to the companies. However, Leventhal [49] proposes that the transactional customer data must be combined with market research on the same individuals to increase the benefits obtained from database marketing. The information gathered from databases must be supported by traditional market research. The measurement of the effectiveness of database marketing efforts reveals whether the consumers respond the offers. However, the use of market research may help in understanding "why" consumers are behaving in the way they do. As a result it can be helpful in guiding the future database marketing strategies.

\section{* A Learning Opportunity}

Database marketing, seen as an organizational learning activity, encompasses ongoing interactions with 
the environment (customers) wherein the organization constantly absorbs and learns to process more and more information appropriately. If the organization is good at learning, the database transcends the status of a record keeping device and becomes an implement of everincreasing organizational knowledge [8].

Organizational learning theory's predictive ability is another benefit for database marketing application. In fact Slater and Narver [50] argue that market-oriented organizational learning is intimately connected to the fundamentals of competitive advantage.

\section{VI.2. Outcomes for Consumers}

For a database marketing strategy to prove successful it is imperative that fundamental focus of the company be on the customer. Unless there is a strong customer focus in the organization, database marketing may not achieve its objectives. The company must accept that it is the customer who is empowered. The company is responsible of identifying and tailoring the products/services, promotions and every communication according to the needs of the customer. As Peppers et al. [45] point out the one-to-one marketing means being willing and able to change the company's behavior toward an individual customer based on what the customer tells you and what else you know about the customer. Naturally, the objective is to create a mutually beneficial relationship between consumers and the company, to their benefit and to the profit of the company.

The customers benefit from database marketing in several ways. Information, recognition, customized products/services and appreciation are the customer benefits that are fundamentals of database marketing [51].

\section{* Information}

Consumers are now more educated and want to be more informed about the products/services they receive. With so many product and service choices available, consumers want to be confident that they are making the best purchase decision. By providing information about their products and services, companies are able to provide a higher level of confidence in their customers' decisions to buy [5].

\section{* Recognition}

The customers want to receive recognition and individual treatment. Tailor-made promotions and any kind of personalized offer make the customers feel important. The company has to show them that they care about customers, they value them and want to please them as individuals. The recognition of needs and wants of each customer make the customer happy as well as providing an advantage to the firms for having established a relationship.

\section{* Customized product/services}

Customers today are demanding more variety of goods and improved customer service. They expect a high level of personalized services/ products and attention. Database marketing allows the marketers to tailor products/services according to the needs of the customers. Pitta [52] states that database marketing aims at customizing a product offering so carefully that it fits the customer perfectly. It is this perfect fit which generally asked by the consumers.

\section{* Appreciation}

The customers also expect to be appreciated for having given their personal information or having shopped from the company. The loyalty promotions providing specific advantages to the customers (e.g. special lounge for card holders at the airport), as stated in the airlines example, are indicators of such an appreciation.

\section{A FEW WORDS ON SOCIETAL AND LEGAL CONSIDERATIONS}

Society as a whole is also expected to benefit from the effective use of database marketing. However, unless database marketing is carried out in a socially responsible and ethical manner, it can harm the individuals as well as the society. To ascertain that database marketers take care about the privacy rights of the consumers, besides the ethical guidelines for companies, laws and regulations are needed.

Today, the gap between the development of technologies and the development of corresponding ethical guidelines for their use is widening and the speed of technology development accelerates without corresponding acceleration in the mechanisms of developing social consensus [53]. The major problem is that there are only very few regulations and restricting laws related with this issue. The European Union Directive on Data Protection (1991) and the Direct Marketing Association's Guidelines are among the few and still very limited ones [54].

In relation to privacy, guidelines and formal codes are needed to determine which customer information in an organization is public and which is private, the conditions under which such information may or may not be collected and shared, and the extent to which the individual has the right to control the recording, maintenance, dissemination and accessibility of information about himself [53]. Among other concerns are whether a company can be allowed to acquire and 
store information about individuals without their knowledge or consent and whether it can be allowed to disclose that kind of information to third parties without the consent of those individuals $[55 ; 56]$. The challenge is to make the most out of the opportunities presented by technology while at the same time protecting what remains of individual privacy [57].

To solve these conflicting issues, there are several views. First of all, it is proposed that although there are no clear-cut rules and regulations, the managers should develop an ethical framework by themselves to cope with new situations consistently [58]. However, the opposing view is that businesses do not have moral obligations beyond the law. So, whatever is not specified by law is ethical and can be applied without reservation [59]. Some researchers argue that the transactions can be more morally defensible if both parties enter them freely and fully informed [60]. Another view, which is in harmony with the value concept in relationship marketing, proposes that the harm done must be balanced by providing certain rewards to the customers [55;61]. Thomas and Maurer [62] state that there must be a balance between consumer privacy rights and industry interests, and care should be taken in developing and changing the law. According to these authors, protecting consumer privacy is costly, and all parties, including the customers, must share this burden in order to maximize the social welfare. Zwick and Dholakia [63] argue that the consumers should be given full access to companies' databases so that they can maintain a sense of control over their identities.

Despite several attempts to establish specific rules and regulations, because of new situations frequently occurring and new applications becoming available, the standardization of the applications to protect the privacy rights of the customers has not yet been achieved. However, as consumer knowledge about information practices continues to increase, the chances for legislation regulating database management practices also increase [64].

\section{CONCLUSION}

In today's competitive marketing environment where the customers are becoming more demanding with diversified needs and expectations, marketers are looking for new ways of reaching and satisfying them. Companies witness that the key for success lies in creating strong bonds with the customers through effective relationship building leading to loyalty. Therefore, it is crucial for marketers to know the relevant demographic and psychographic characteristics of their customers and develop marketing strategies based upon this knowledge.

As a result of the development in the information technologies, today's marketers can gather all the information available about their customers, and prospects into a central database and use that information to drive targeted marketing efforts. A company that utilizes database marketing should continually gather, refine, and analyze data about their customers, their buying history, prospects, past marketing efforts, demographics, and so forth. Database marketing enables the companies to transform the customer data into valuable knowledge which will drive the marketing efforts of the company towards a targeted group of people in order to increase effectiveness of the marketing activities. Some of the marketing companies also use the customer information, to tailor marketing efforts right down to the individual level.

As pointed out in the study, effective applications of database marketing provide many opportunities to the companies. First of all, database marketing enables marketers to segment their market more efficiently and offer individualized choices to their customers without the cost of retail marketing. The differentiation of the offers according to the specific needs of particular customers creates a competitive advantage for the company. The information gathered also serves for the development of new products and the quality improvements of existing products and services. The ultimate aim of database marketing is creating customer loyalty and building enduring profitable relationships with customers. Therefore, the loyalty programs applied in different sectors are carried out with the objective of increasing customer retention and loyalty. Furthermore, the database marketing provides an opportunity for learning to the company. Through increased organizational learning the database becomes a valuable organizational knowledge. It has to be also mentioned that, one of the major strengths of database marketing is its measurable effectiveness.

Customers also are aware of the value of the information that they provide about themselves. Therefore, they are looking for compensation and expect to be provided certain advantages. They look for further information, recognition, customized products and services, and appreciation. The key term for success should be "the mutual benefit": the customer knowledge should be used to the benefit of the company as well as that of the customers. It is this "win-win situation" that will build the path for long lasting profitable relationships with the customers.

Today, companies which are centering their business on their customers rather than their products are becoming more successful. It is database marketing which enables companies to communicate directly with clearly defined market segments in an interactive and cost-effective manner.

It has to be noted that, adopting a database marketing strategy can be considered as a new way of doing business, requiring an organizational change. The 
commitment of the top management is considered to be crucial for successful implementation. From a short-term perspective, the method can be considered as costly because it requires heavy investments. However, from a long-term perspective and strategic point of view, the companies can benefit from it extensively. An inevitable prerequisite for the adoption of such an approach is customer-focus. Unless there is a desire to better understand and better serve the customer the database marketing can not reach its full potential. It is also essential that the ethical issues be taken into consideration when implementing database marketing in order to establish long-term, mutually beneficial relationships with the customers. Finally, the marketers must realize that database marketing is not an option for the future but is a necessity today, to achieve customer loyalty and create competitive advantage.

\section{REFERENCES}

[1] Kunoe, G. (1998). On the Ability of Ad Agencies to Assist in Developing One-to-one Communication. European Journal of Marketing, 32(11\12), 1124-1137.

[2] Cooke, S. (1994). Database Marketing: Strategy or Tactical Tool? Marketing Intelligence \& Planning, 12(6), 4-7.

[3] Stone, B. (1997). Successful Direct Marketing Methods. Chicago: NTC/Contemporary Publishing Company.

[4] Brown, S. (1993). Postmodern Marketing? European Journal of Marketing, 27(4), 19-35.

[5] Schoenbachler, D.D.; Gordon, G.L.; Foley, D. \& Spellman, L. (1997). Understanding Consumer Database Marketing. Journal of Consumer Marketing, 14(1), 5-19.

[6] Roberts, M.L. \& Berger, P.D. (1989). Direct Marketing Management. New Jersey: Prentice-Hall, Inc.

[7] Forcht, K.A. \& Cochran, K. (1999). Using Data Mining and Data Warehousing Techniques. Industrial Management\&Data Systems, 99(5), 189-196.

[8] DeTienne, K.B. \& Thompson, J.A. (1996). Database Marketing and Organizational Learning Theory: Toward a Research Agenda. Journal of Consumer Marketing, 13(5), 12-34.

[9] Fletcher, K.; Wheeler, C. \& Wright, J. (1994). Strategic Implementation of Database Marketing: Problems and Pitfalls. Long Range Planning, 27(1), 133-141.

[10] O'Malley, L. \& Tynan, C. (2000). Relationship in Consumer Markets: Rhetoric or reality? European Journal of Marketing, 34(7), 797-815.
[11] Duffy, D.L. (1998). Customer Loyalty Strategies. Journal of Consumer Marketing, 15(5), 435-448.

[12] Voss, G.B. \& Voss, Z.G. (1997). Implementing a relationship marketing Program: A Case Study and Managerial Implications. Journal of Services Marketing, 11(4), 278-298.

[13] Evans, M. (1998). From 1086 and 1984: Direct Marketing into the Millennium. Marketing Intelligence \& Planning, $16(1), 56-67$

[14] Shepard, D. (1999). The Next Direct Marketing. New York: Mc-Graw Hill.

[15] Ravald, A. \& Grönroos, C. (1996). The Value Concept and Relationship Marketing. European Journal of Marketing, 30(2), 15-30.

[16] (1997). Hi Ho Hi Ho Down the Data Mine We Go. Economist, August 23, 49-50.

[17] Blattberg, R.C. \& Deighton, J. (1991). Interactive Marketing: Exploiting the Age of Addressability. Sloan Management Review, 33(1), 5-15.

[18] Nancarrow, C. \& Penn, S. (1998). Rapport in Telemarketing- Mirror, Mirror on the Call? Marketing Intelligence Planning, 16(1), 12-21.

[19] O'Leary, C.; Rao, S. \& Perry C. (2004). Improving Customer Relationship Management Through Database/Internet Marketing. European Journal of Marketing, 38(3/4), 338-354

[20] Fairlie, R. (1993). Database Marketing and Direct Mail. London: Kogan Page Ltd.

[21] Glazer, R. (1991). Marketing in an Information-Intensive Environment: Strategic Implications of Knowledge as an Asset. Journal of Marketing, 55(4), 1-19.

[22] Riesenberger, J.R. (1998). Executive Insights: Knowledge- The Source of Sustainable Competitive Advantage. Journal of International Marketing, 6(3), 94107.

[23] Talvinen, J.M. (1995). Information Systems in Marketing. European Journal of Marketing, 29(1), 8-26.

[24] Peattie, K. \& Peters, L. (1997). The Marketing Mix in the third Age of Computing. Marketing Intelligence Planning, $15(3), 142-150$.

[25] Porter, M.E \& Millar, V.E. (1985). How Information Gives You Competitive Advantage. Harvard Business Review, 63(4), 149-160. 
[26] Fletcher, K. \& Peters, L. (1996). Issues in Customer Information Management. Journal of the Market Research Society, 38(2), 145-160.

[27] Glazer, R. (1997). Strategy and Structure in InformationIntensive Markets: The Relationship Between Marketing and IT. Journal of Market Focused Management, 2(1), 6581 .

[28] Zineldin, M. (2000). Beyond Relationship Marketing: Technologicalship Marketing. Marketing Intelligence \& Planning, 18(1), 9-23.

[29] Hutton, J.G. (1996). Integrated Marketing Communication and the Evolution of the Marketing Thought? Journal of Business Research, 37(3), 155-162.

[30] (1987). Direct Marketing Revolution. Focus, May, (2), 1013.

[31] Opperman, M. (1999). Database Marketing by Trave Agents. Journal of Travel Research, 37(3), 231-238.

[32] Shaver, D. (1996). The Next Step in Database Marketing: Consumer Guided Marketing. Canada: John Wiley \& Sons, Inc.

[33] Ruediger, A.; Grant-Thompson, S.; Harrington, W. \& Singer, M. (1997). Current Research: What Leading Banks Are Learning About Big Databases and Marketing. Mckinsey Quarterly, (3), 187-192.

[34] Fishman, C. (1999). This Is a Marketing Revolution. Fast Company, 24(5), 204-213.

[35] Labe, R.P.Jr. (1994). Database Marketing Increases Prospecting Effectiveness at Merrill Lynch. Interfaces, $24(5), 1-12$.

[36] Iyer, R.T. \& Hill, J.S. (1996). International Direct Marketing Strategies: A US- European Comparison. European Journal of Marketing, 30(3), 65-83.

[37] Nash, E. (1994). Familiarity Breeds Sales; Using Database Marketing to Help Spur Loyalty from Customers. Sales and Marketing Management, 146(6), 33-34.

[38] Berry, J.\& Verity J. (1994), A Potent New Tool for Selling: Database Marketing. Business Week, 3388, 56-62.

[39] Woodside, A.G. (1994). Modeling Linkage- Advertising: Going Beyond Better Media Comparisons. Journal of Advertising Research, 34(4), 22-31.

[40] Altınbaşak, I. \& Alvarez, M.D. (2001). A Model of Database Marketing and Managers' Perception of Intrusion of Privacy: An Emerging Country's Perspective. Proceedings of World Marketing Congress on Global Marketing Issues at the Turn of the Millennium. (10), Cardiff, United Kingdom: Academy of Marketing Science and Cardiff University.
[41] Grover, R. \& Srinivasan, V. (1989). An approach for Tracking Within-Segment Shifts in Market Shares. Journal of Marketing Research, 26(2), 230-236.

[42] Kara, A. \& Kaynak, E. (1997). Markets of a Single Customer: Exploiting Conceptual Developments in Market Segmentation. Single European Journal of Marketing, 31(11/12), 873-895.

[43] Knudsen, P. (1996). Marketing in the Modern Private Company. New Library World, 97(1129), 12-16.

[44] Hughes, A.M.\& Gilyeat I.R (2007). Database Marketing Drives New Corporate Strategy: How a Major Direct Marketer Changed from Inbound to Outbound Selling in Two Years. Database Marketing Institute. (http://www.dbmarketing.com/articles/Art178.htm). [13/11/2007]

[45] Peppers, D.; Rogers, M. \& Dorf, B. (1999). Is Your Company Ready for One-to-one. Harvard Business Review, 77(1), 151-160.

[46] Feinberg, R.A. \& Eastlick, M.A. (1997). Direct Marketing in the USA: Past Failures and Future Promises. International Journal of Retail Distribution Management $25(8), 256-262$

[47] Chandler, S. (1994), "Strategies for the New Mail Order", Business Week, 3404, 34-37.

[48] Kamakura, W.A., Wedel, M., de Rosa, F.\& Mazzon, J.A. (2003), International Journal of Research in Marketing, $20(1), 45-65$

[49] Leventhal, B. (1997). An Approach to Fusing Marke Research with Database Marketing. Journal of the Market Research Society, 39(4), 545-558.

[50] Slater, S.F. \& Narver, J.C. (1995). Market Orientation and the Learning Organization. Journal of Marketing, 59(3), $63-74$

[51] Kahan, R. (1998). Using Database Marketing Techniques to Enhance Your One-to-one Marketing Initiatives. Journal of Consumer Marketing, 15(5), 491-493.

[52] Pitta, D.A. (1998). Marketing One-to-one and Its Dependence on Knowledge Discovery in Databases. Journal of Consumer Marketing, 15(5), 468-480.

[53] Marshall, K.P. (1999). Has Technology Introduced New Ethical problems? Journal of Business Ethics, 19(1), 8190.

[54] Nettleton, E.\& Obhi, H. (2004). Journal of Database Marketing and Customer Strategy Management, 11(3), 268-273.

[55] Bloom, P.N.; Milne, G.R. \& Adler, R. (1994). Avoiding Misuse and New Information Technologies: Legal and Societal Considerations. Journal of Marketing, 58(1), 98110. 
[56] Lally, L. (1996). Privacy Versus Accessibility: The Impact of Situationally Conditioned Belief. Journal of business Ethics, 15(11), 1221-1226.

[57] Pincus, L.B. \& Johns, R. (1997). Private Parts: A global Analysis of Privacy protection Schemes and a Proposed Innovation for their Comparative Evaluation. Journal of Business Ethics, 16(12/13), 1237-1260.

[58] Cordeiro, W.P. (1997). Suggested Management Responses to Ethical Issues Raised by Technological Change. Journal of Business Ethics, 16(12/13), 1393-1400.

[59] Fieser, J. (1996). Do Business Have Moral Obligations Beyond What the Law Requires? Journal of Business Ethics, 15(4), 457-468.

[60] Kavali, S.G.; Tzokas, N.X. \& Saren, M.J. (1999). Relationship Marketing as An Ethical Approach: Philosophical and Managerial Considerations. Management Decision, 37(7), 573-581.

[61] Takala, Tuorno \& Ulusitalo, O. (1996). An Alternative View of Relationship Marketing: A Freamework for Ethical Analysis. European Journal of Marketing, 30(2), 45-64.

[62] Thomas, R.E. \& Maurer, V.G. (1997). Database Marketing Practice: Protecting Consumer Privacy. Journal of Public Policy and Marketing, 16(1), 147-155.

[63] Zwick, D.\& Dholakia, N. (2004). Journal of Macromarketing, 24(1), 31-43.

[64] Milne, G.R. (1997). Consumer Participation in Mailing Lists: A Field Experiment. Journal of Public Policy and Marketing, 16(2), 289-309.
İpek ALTINBAŞAK(ipek.altinbasak@bahcesehir.edu.tr) received her $\mathrm{BA}$ degree in Business Administration from Boğaziçi University in İstanbul, Turkey and her MBA from West Georgia University in the United States. After graduation, she worked for several years as brand manager, marketing manager, new product development director and corporate communication consultant in FMCG and telecommunications sectors in multinational companies. She then returned to academics and received her PhD in marketing from Boğaziçi University in 2004.

Altinbasak has been a member of the Faculty of Economics and Administrative Sciences at Bahçeşehir University since 2004 and she was also the director of the Institute of Social Sciences between the years 2005-2007. Among the courses she has been giving are the Principles of Marketing, Consumer Behavior, Services Marketing and Management and Global Marketing. 